\title{
Increased islet DNA synthesis and glucose-derived lipid and amino acid production in association with beta-cell hyperproliferation in normoglycaemic $60 \%$ pancreatectomy rats
}

\author{
Y. Q. Liu ${ }^{1}$, E.Montanya ${ }^{2}$, J.L.Leahy ${ }^{1}$ \\ ${ }^{1}$ Division of Endocrinology, Diabetes and Metabolism, University of Vermont College of Medicine, Burlington, Vermont, USA \\ ${ }^{2}$ Endocrine Unit, CSUB-Hospital Bellvitge, Barcelona, Spain
}

\section{Abstract}

Aims/hypothesis. Glycaemia does not change following a $60 \%$ pancreatectomy in rats because of enhanced beta-cell function and proliferation (so-called beta-cell adaptation). We previously studied these rats 4 weeks after surgery and showed hypersensitization of glucose-induced insulin secretion because of increased glucokinase activity. In this study of $60 \%$ pancreatectomy rats 5 days after surgery, when betacell proliferation increased threefold, we investigated whether increases in glucose metabolism enhance the production of glucose-derived lipid, amino acids and DNA.

Methods. Isolated islets from $60 \%$ pancreatectomy and sham-operated control rats 5 days or 4 weeks after surgery were studied.

Results. Five days after $60 \%$ pancreatectomy surgery, islet glucose phosphorylation increased threefold, but overall glucose usage increased only twofold. The glucose-6-phosphate (G6P) concentration thus doubled, resulting in a sixfold increase in G6P metabolism through the pentose phosphate shunt (PPS). The pentose phosphate shunt generates ribose-5- phosphate for nucleotide synthesis, and DNA synthesis doubled in the partial pancreatectomy islets. In contrast, partial pancreatectomy rats 4 weeks after surgery had a smaller increase in glucokinase activity and their islet glucose-6-phosphate concentration and pentose phosphate shunt activity were equal to that of the control rats. DNA synthesis and beta-cell proliferation, based on BrdU incorporation were close to normal. Another consequence of the heightened glucose metabolism in the 5-day partial pancreatectomy islets was twofold increase in production of glucose-derived lipid and the amino acids, alanine and glutamate.

Conclusions/interpretation. The enhanced glucokinase activity in $60 \%$ pancreatectomy rats supports the compensatory beta-cell hyperproliferation by increasing production of glucose-derived DNA, lipids and amino acids. [Diabetologia (2001) 44: 1026-1033]

Keywords Beta-cell adaptation, glucose metabolism, phosphofructokinase, islets of Langerhans, glucose6-phosphate, glucokinase, pentose phosphate shunt, glucose-6-phosphate.
The glucose homeostasis system maintains normoglycaemia by adapting the mass and function of beta-

Received: 8 February 2001 and in revised form: 12 April 2001

Corresponding author: Jack L. Leahy, University of Vermont College of Medicine, Given C331, Burlington, VT 05405, Email: jleahy@zoo.uvm.edu

Abbreviations: Px, partial pancreatectomy; G6P, glucose-6phosphate; PPS, pentose phosphate shunt; PFK, phospofructokinase; G6PD, glucose-6-phosphate dehydrogenase; 6-PGD, 6-phosphogluconate dehydrogenase cells that counter insulin resistance, a lowered betacell mass or an excess nutrient intake. It is often assumed that hyperglycaemia is the stimulatory force for beta-cell adaptation through the well-known regulatory effects of glucose on insulin secretion, proinsulin synthesis and beta-cell proliferation [1-4]. However, healthy subjects with obesity-associated insulin resistance have higher insulin secretion compared with non-obese control subjects when glycaemia is identical in the two groups [5]. We made the same observation in two rat models of beta-cell adaptation: 
following a $60 \%$ pancreatectomy $(\mathrm{Px})$ to lower the beta-cell mass and in insulin-resistant spontaneously hypertensive rats $[6,7]$. In both, the activity of glucokinase, the major regulatory enzyme in beta-cells for glycolysis, increased [6-8]. Thus, their normal glycaemia elicited a heightened beta-cell glycolytic flux and consequently higher than normal insulin secretion as signals derived from beta-cell glucose metabolism regulate insulin secretion through well-characterized effects on ion channels and membrane potential $[1,4]$.

Recent studies suggest a role for glucokinase in compensatory beta-cell growth because of the observation that a high fat diet failed to induce the expected beta-cell hyperplasia in heterozygous glucokinase-deficient mice [9]. The mechanism of this effect is not known. Beta-cell glucose metabolism generates not only energy but also lipid and amino acids for signalling and structural macromolecules [10]. Also, the precursor for nucleotide synthesis, ribose-5-phosphate, is derived from the pentose phosphate shunt which is a metabolic pathway of the glucokinase reaction product, glucose-6-phosphate (G6P) [11].

We tested the hypothesis that the enhanced glucokinase activity of beta-cell adaptive states increases the production of glucose-derived lipid, amino acids and DNA. Rats following a $60 \%$ pancreatectomy were studied and found to maintain normal plasma concentrations of insulin and glucose despite the large reduction in beta-cell mass [6,12], making them an excellent model to investigate beta-cell compensation. The study was carried out when beta-cell proliferation was increased by threefold ( 5 days after surgery) and near normal (4 weeks after surgery).

\section{Materials and methods}

Rats and islet isolation. Principles of laboratory animal care (NIH publication no. 85-23, revised 1985) were followed and the protocol was approved by the Institutional Animal Use and Care Committee of the University of Vermont. SpragueDawley rats $(100 \mathrm{~g})$ underwent a $60 \%$ Px using our previously described method [12]. Briefly, the portion of the pancreas bordered by the spleen and stomach extending to the pylorus was removed with gentle abrasion using cotton applicators. Control rats underwent laparotomy and mobilization of the pancreas with gentle rubbing between the fingers. All rats received rat chow and tap water ad libitum, and were studied 5 days or 4 weeks after the surgery unless stated otherwise. Plasma glucose was measured in tail vein blood from normally fed rats using a Glucose Analyser II (Beckman, Fullerton, Calif., USA). Islets were isolated by an adaptation of the Gotoh method [13]: pancreas duct infiltration was with collagenase, Histopaque gradient separation and hand picking. DNA was measured by the Labarca method [14], and protein by commercial (Bio-Rad, Hercules, Calif., USA) kit that used BSA as standard. Freshly isolated islets were used after $30 \mathrm{~min}$ incubation in KRB, $5.5 \mathrm{mmol} / 1$ glucose, $0.07 \%$ BSA unless stated otherwise.
Insulin secretion. Isolated islets underwent a $30 \mathrm{~min}$ preincubation in warmed and oxygenated KRB, $2.8 \mathrm{mmol} / \mathrm{l}$ glucose, $0.5 \%$ BSA. Insulin secretion was assessed using duplicate batches of $10-15$ islets in glass vials containing $1 \mathrm{ml} \mathrm{KRB}$, $0.5 \%$ BSA, $5.5,8.3$ or $16.7 \mathrm{mmol} / 1$ glucose for $60 \mathrm{~min}$ in a $37^{\circ} \mathrm{C}$ shaking water bath. Medium was separated and stored at $-20^{\circ} \mathrm{C}$ pending insulin measurement by RIA [15]. Islet protein content in each sample was measured and the secretion results expressed as nmol $\mu \mathrm{g}$ protein $^{-1}$.

Glucose phosphorylation and glucokinase immunoblot. Glucose phosphorylation was measured in the supernatant of homogenized islets after centrifugation at $12000 \mathrm{~g}$ for $10 \mathrm{~min}$ as previously described [7] by quantifying conversion of $\mathrm{NAD}^{+}$ to NADH by exogenous glucose-6-phosphate dehydrogenase [16]. The reaction was carried out at $0.06,0.5,6.0$ and $24 \mathrm{mmol} / \mathrm{l}$ glucose, as the limited number of islets from $60 \%$ Px rats prevented our using the 10 glucose concentrations that are typically used to calculate glucokinase and hexokinase kinetics. Hexokinase activity was estimated as the value at $0.5 \mathrm{mmol} / \mathrm{l}$ glucose and glucokinase activity as the difference between the 0.5 and $24 \mathrm{mmol} / \mathrm{l}$ glucose measures. Glucokinase immunoblots were done as described [7] using sheep antiserum against an Ecoli-derived B1 isoform of rat glucokinase (gift of Dr. Mark Magnuson, Vanderbilt University, Nashville, Tenn., USA) and chemiluminescence detection.

Pentose phosphate shunt activity (PPS). The proportion of islet glucose metabolism attributable to the PPS pathway was calculated by the method as previously described [17]. Islet glucose oxidation measured using $90 \mathrm{~min}$ incubations at $37^{\circ} \mathrm{C}$ with $\left[1-{ }^{14} \mathrm{C}\right]$ glucose and $\left[6-{ }^{14} \mathrm{C}\right]$ glucose at $2.8,8.3$ or $27.7 \mathrm{mmol} / \mathrm{l}$ glucose was stratified against glucose utilization measured with $\mathrm{D}-\left[5-{ }^{3} \mathrm{H}\right]$ glucose to yield pmol glucose oxidized or utilized for each tracer (glucose oxidation specific yield). PPS (\% of glucose metabolism) was calculated from the equation:

$\underline{\left[1-{ }^{14} \mathrm{C}\right] \text { glucose specific yield }-\left[6-{ }^{14} \mathrm{C}\right] \text { glucose specific yield }}=\frac{3 \text { PPS }}{1+2 \text { PPS }}$

$$
1-\left[6-{ }^{14} \mathrm{C}\right] \text { glucose specific yield }=\frac{3 \mathrm{PPS}}{1+2 \mathrm{PPS}}
$$

Absolute PPS activity was calculated as the PPS relative percentage of glucose metabolism multiplied by the glucose utilized at that experimental condition as determined from D$\left[5-{ }^{3} \mathrm{H}\right]$ glucose.

DNA synthesis. A total of 100 islets were incubated for $4 \mathrm{~h}$ at $37^{\circ} \mathrm{C}$ in $2 \mathrm{ml} \mathrm{RPMI} 1640$ that contained $8.3 \mathrm{mmol} / \mathrm{l}$ glucose +2 $\mu \mathrm{Ci}\left[{ }^{3} \mathrm{H}\right]$ thymidine. Incorporation of $\left[{ }^{3} \mathrm{H}\right]$ thymidine into DNA was measured by a method previously described [18]: $10 \%$ TCA-treated islet samples were vacuum-filtered through a GF/F glass microfiber filter (Whatman, Clifton, N. J., USA) to trap DNA, washed with cold 5\% TCA then $75 \%$ ethanol and the filters were scintillation counted.

Glucose-derived lipid production. Altogether 100 islets were incubated for $3 \mathrm{~h}$ at $37^{\circ} \mathrm{C}$ in $200 \mu \mathrm{KRB}$ that contained 2.8, 8.3 or $27.7 \mathrm{mmol} / 1$ glucose $+4 \mu \mathrm{Ci}\left[\mathrm{U}-{ }^{14} \mathrm{C}\right]$ glucose. Glucose-derived lipid was determined by liquid scintillation counting of chloroform-methanol extracts [19].

Glucose-derived alanine and glutamate production. A total of 100 islets were incubated for $3 \mathrm{~h}$ at $37^{\circ} \mathrm{C}$ in $100 \mu \mathrm{KRB}$ that contained $2.8,8.3$ or $27.7 \mathrm{mmol} / 1$ glucose $+1 \mu \mathrm{Ci}\left[6-{ }^{14} \mathrm{C}\right]$ glucose. Glucose-derived alanine and glutamate were measured as the difference of ${ }^{14} \mathrm{C}$-labelled amino acids in sample $\mathrm{A}$ $(40 \mu \mathrm{l}$ islet homogenate in $60 \mu \mathrm{l} 100 \mathrm{mmol} / \mathrm{l}$ TRIS, $\mathrm{pH} 8.1$, $20 \mathrm{mmol} / \mathrm{l}$ oxoglutarate, $20 \mathrm{mmol} / \mathrm{l} \mathrm{L}$-glutamate) and B (40 $\mu \mathrm{l}$ 
islet homogenate in $60 \mu \mathrm{l} 100 \mathrm{mmol} / \mathrm{l} \mathrm{TRIS}, \mathrm{pH} 8.1,20 \mathrm{mmol} / \mathrm{l}$ oxoglutarate and $83 \mu \mathrm{g} / \mathrm{ml}$ pig heart glutamate: pyruvate transaminase) according to a method previously described [20].

Enzyme activities. Phosphofructokinase (PFK) activity was measured as previously described [21]. Islets $(100 / 0.1 \mathrm{ml} \mathrm{ex}-$ traction buffer) were sonicated on ice in $15 \mathrm{mmol} / \mathrm{l} \mathrm{K} \mathrm{PO}_{4}$, $\mathrm{pH} 7.0,100 \mathrm{mmol} / \mathrm{l} \mathrm{KCl}, 2 \mathrm{mmol} / \mathrm{l}$ EDTA, $2 \mathrm{mmol} / \mathrm{l} \mathrm{PMSF}$, $0.2 \mathrm{mg} / \mathrm{ml}$ leupeptin, $50 \mu \mathrm{g} / \mathrm{ml}$ aprotinin, then centrifuged at $12000 \mathrm{~g}$ for $15 \mathrm{~min}$ at $4{ }^{\circ} \mathrm{C}$. Supernatant $(20 \mu \mathrm{l})$ was added to $1 \mathrm{ml}$ reaction buffer containing $50 \mathrm{mmol} / \mathrm{l} \mathrm{TRIS} / \mathrm{HCl}, \mathrm{pH} 8.0$, $1 \mathrm{mmol} / \mathrm{l} \mathrm{EDTA,} 2.5 \mathrm{mmol} / \mathrm{l} \mathrm{DTT}, 2 \mathrm{mmol} / \mathrm{l} \mathrm{MgCl} 2,5 \mathrm{mmol} / \mathrm{l}$ ammonium sulphate, $1 \mathrm{mmol} / \mathrm{l}$ ATP, $1 \mathrm{mmol} / \mathrm{l}$ Fru 6-P, $0.16 \mathrm{mmol} / 1 \mathrm{NADH}, 0.4 \mathrm{U} / \mathrm{ml}$ aldolase, $2.4 \mathrm{U} / \mathrm{ml}$ triosephosphate isomerase $/ 0.8 \mathrm{U} / \mathrm{ml}$ glycerophosphate dehydrogenase mixture in a quartz cuvette and $\mathrm{NADH}$, metabolized over $15 \mathrm{~min}$, assessed by spectrophotometer at $340 \mathrm{~nm}$. The PFK activity was calculated based on $1 \mu \mathrm{mol}$ Fru 1,6-P2 $=2 \mu \mathrm{mol}$ NADH consumed.

Citrate synthase activity was measured as previously described [22]. Homogenized islet extract in HEPES $10 \mathrm{mmol} / \mathrm{l}$ $\mathrm{pH} 7.4,250 \mathrm{mmol} / \mathrm{l}$ sucrose, $2.5 \mathrm{mmol} / 1 \mathrm{EDTA}, 2 \mathrm{mmol} / \mathrm{l} \mathrm{cys}-$ teine, $0.02 \% \mathrm{BSA}(40 \mu \mathrm{l})$ was added to $0.55 \mathrm{ml} 100 \mathrm{mmol} / \mathrm{l} \mathrm{He}$ pes, $\mathrm{pH} 7.4,0.1 \mathrm{mmol} / \mathrm{l}$ oxaloacetate, $0.1 \mathrm{mmol} / \mathrm{l}$ DTNB, $0.05 \mathrm{mmol} / \mathrm{l}$ acetyl-CoA in a UV cuvette. CoA-SH production was assessed spectrophotometrically at $412 \mathrm{nmol}$.

Glucose-6-phosphate dehydrogenase (G6PD) and 6-phosphogluconate dehydrogenase (6-PGD) activities were measured in the supernatant of 100 islets that were sonicated in $20 \mathrm{mmol} / \mathrm{l} \mathrm{HEPES}$, pH 7.4, $50 \mathrm{mmol} / \mathrm{l} \mathrm{KCl}, 0.5 \mathrm{mmol} / \mathrm{l} \mathrm{DTT}$, and centrifuged at $14000 \mathrm{~g}$ for $10 \mathrm{~min}$. 6-PGD activity alone and total dehydrogenase activity (G6PD and 6-PGD) were measured according to a method previously described [23]. G6PD activity was calculated as the difference between the activity of 6-PGD and total dehydrogenase activity.

Metabolites. Freshly isolated islets were incubated for $1 \mathrm{~h}$ at $37^{\circ} \mathrm{C}$ in prewarmed and oxygenated KRB followed by biochemical analysis. Citrate concentration was measured as previously described [21] by the method of Lowry and Passonneau [24] after a 60 -min incubation at $37^{\circ} \mathrm{C}$ in $8.3 \mathrm{mmol} / 1$ glucose. Glucose-6-phosphate (G6P) was measured after incubation at $2.8,8.3$ or $27.7 \mathrm{mmol} / \mathrm{l}$ glucose using an adaptation of the Lowry and Passonneau method [25] as previously described [22]. The method first entailed rapid lysis after incubation using $10 \mu \mathrm{l} 40 \mathrm{mmol} / \mathrm{l} \mathrm{NaOH}$, placed on ice for $10 \mathrm{~min}$ and addition of $3 \mu \mathrm{l} 0.15 \mathrm{~mol} \mathrm{HCl}$ with incubation at $75^{\circ} \mathrm{C}$ for $20 \mathrm{~min}$ to destroy cellular enzymes to ensure stability of the G6P.

Beta-cell replication by 5-bromodeoxyuridine (BrdU) incorporation. The method has been described before [26]. Px and control rats 2 days, 5 days and 4 weeks after surgery were injected with $100 \mathrm{mg} / \mathrm{kg}$ BrdU ip (Sigma, St. Louis, Mo., USA). Pancreata were harvested $6 \mathrm{~h}$ later and placed in Bouin's fixative overnight, then shipped to Barcelona for the remainder of the protocol. Paraffin-embedded $5 \mu \mathrm{m}$ sections were double-stained by immunoperoxidase for BrdU (Amersham, Piscataway, N.J., USA) and for beta cells using a guinea pig antiswine insulin antibody (Dako, Carpinteria, Calif., USA). Beta-cells were systematically counted using an Olympus $\mathrm{BH}-2$ microscope connected to a video camera with a color monitor. Results are expressed as percent of beta cells that stained for BrdU (at least 1200 beta cells were counted for each animal).

Data presentation. All data are expressed as means \pm SEM. For the protocols that used isolated islets from a single rat,

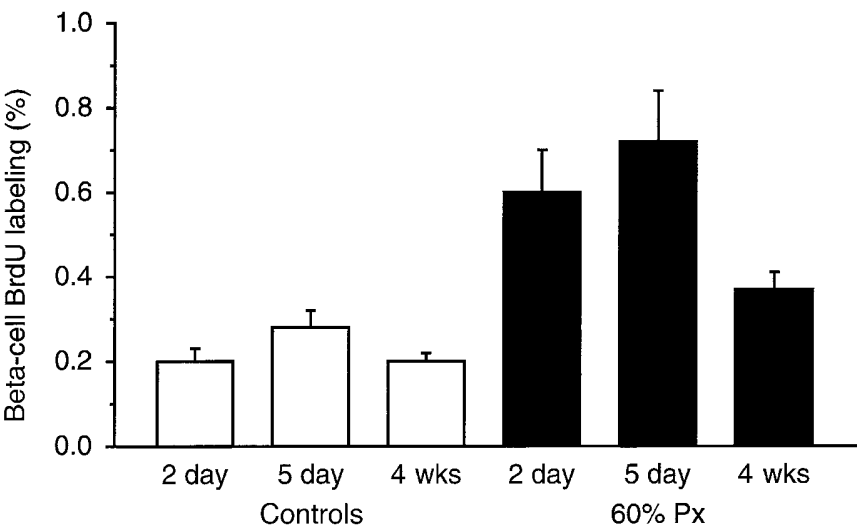

Fig. 1. Islet beta-cell replication rate by BrdU incorporation. Beta-cell replication rate was assessed in $60 \% \mathrm{Px}$ and control rats 2 days, 5 days, and 4 weeks after surgery (3-6 rats per group) by BrdU incorporation measured from pancreas sections that were co-stained for insulin to immunomark beta cells as described in the text. The BrdU treatment period was $6 \mathrm{~h}$. Px values are $258 \pm 42 \%$ at 2 days $(p<0.003), 307 \pm 50 \%$ at 5 days $(p<0.01)$, and $158 \pm 19 \%$ at 4 weeks $(p<0.015)$ of the control rats

the $n$ values are the number of rats studied. If pooled islets from more than one rat were needed, the $n$ values are the number of experiments that were performed. Statistical significance was determined by the unpaired Student's $t$ test unless stated otherwise.

\section{Results}

Characteristics of rats and isolated islets. We previously reported islet and in vivo characteristics of $60 \% \mathrm{Px}$ rats 4 weeks after surgery [6]. Five days after surgery, non-fasting plasma glucose values were equal in the $\mathrm{Px}$ and control rats $(8.1 \pm 0.2 \mathrm{mmol} / \mathrm{l}$ control rats $n=4$ vs $7.9 \pm 0.1 \mathrm{mmol} / 1 \mathrm{Px} n=8)$. Beta-cell BrdU incorporation was threefold higher in the Px rats 2 and 5 days after surgery but had fallen to $150 \%$ of the control rats at 4 weeks (Fig.1). Consequently, isolated islets of the 5-day Px rats were larger and hypercellular compared to the control rats $(0.68 \pm 0.02 \mu \mathrm{g}$ protein islet ${ }^{-1}$ control rats vs $1.21 \pm 0.03 \mu \mathrm{g}$ protein islet $^{-1} \mathrm{Px}, p<0.001 ; 23 \pm 1 \mathrm{ng}$ DNA islet ${ }^{-1}$ control rats vs $40 \pm 2$ ng DNA islet ${ }^{-1}$ Px, $p<0.001, n=6$ both parameters). Islet glucose phosphorylation was also greatly increased at the 5-day time point in the $\mathrm{Px}$ rats (Fig. 2) with threefold increases at $0.5 \mathrm{mmol} / \mathrm{l}$ glucose to approximate hexokinase activity $\left(9.3 \pm 0.9\right.$ mol glucose $\mathrm{kg} \mathrm{DNA}^{-1} 60 \mathrm{~min}^{-1} \mathrm{Px}$ vs $2.9 \pm 0.3$ mol glucose $\mathrm{kg} \mathrm{DNA}^{-1} 60 \mathrm{~min}^{-1}$ control rats, $p<0.001$ ) and in the delta of the results at $0.5 \mathrm{mmol} / \mathrm{l}$ and $24 \mathrm{mmol} / \mathrm{l}$ glucose to approximate glucokinase activity $(10.3 \pm 1.0 \mathrm{~mol}$ glucose $\mathrm{kg}$ DNA $^{-1} 60 \mathrm{~min}^{-1} \mathrm{Px}$ vs. $3.5 \pm 0.0 \mathrm{~mol}$ glucose $\mathrm{kg}$ $\mathrm{DNA}^{-1} 60 \mathrm{~min}^{-1} \mathrm{Px}$ vs $3.5 \pm 0.0 \mathrm{~mol}$ glucose $\mathrm{kg}$ $\mathrm{DNA}^{-1} 60$ min shams, $\left.p<0.001\right)$. The increase in glu- 


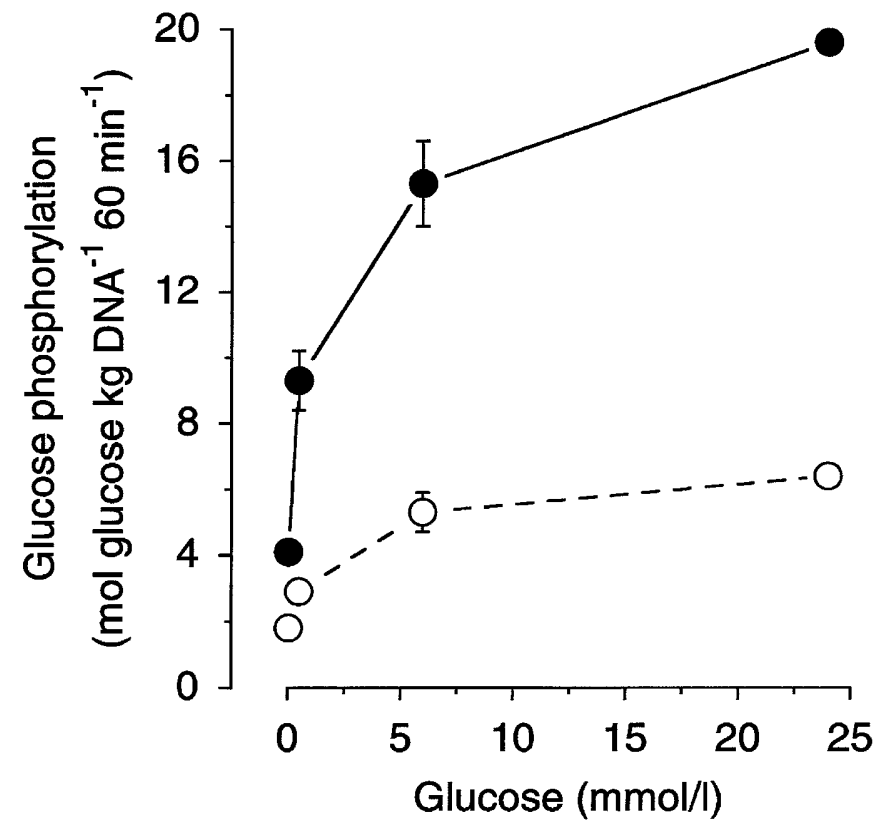

Fig. 2. Islet glucose phosphorylation. Glucose phosphorylation $(n=3$ experiments) was measured after 90 min incubation at the shown glucose concentrations in islets from rats 5 day after $60 \%$ Px or control Px. Values at $0.5 \mathrm{mmol} / 1$ glucose to approximate hexokinase activity and in the delta of the results at $0.5 \mathrm{mmol} / \mathrm{l}$ and $24 \mathrm{mmol} / \mathrm{l}$ glucose to approximate glucokinase activity were increased by threefold in the $60 \%$ Px rats (both $p<0.001)$

cokinase activity occurred with no change in glucokinase content according to immunoblotting (Fig. 3). Mean band intensity from three experiments was Px $107 \pm 14 \%$ of the control islets.

Islet insulin secretion. Insulin secretion measured at $5.5,8.3$ and $16.7 \mathrm{mmol} / \mathrm{l}$ glucose in isolated islets of 5-day post surgery $60 \% \mathrm{Px}$ and control rats did not differ between the two groups (Fig. 4).

Islet PPS activity and DNA synthesis. Glucose utilization measured as $\mathrm{D}-\left[5-{ }^{3} \mathrm{H}\right]$ glucose conversion to $\left[{ }^{3} \mathrm{H}\right]-$ $\mathrm{H}_{2} \mathrm{O}$ was 1.5 -fold to twofold greater in Px islets than the control islets (Table 1$)$. The $\left[1-{ }^{14} \mathrm{C}\right]$ glucose and $\left[6-{ }^{14} \mathrm{C}\right]$ glucose conversion rates to $\left[{ }^{14} \mathrm{C}\right]-\mathrm{CO}_{2}$ also are shown: the 1 isomer, but not the 6 isomer, when metabolized through 6-PGD releases $\left[{ }^{14} \mathrm{C}\right]-\mathrm{CO}_{2}$ so the difference in measured values reflects PPS activity. The PPS activity was $1.8-3.4 \%$ of metabolized glucose in control islets. It was threefold higher in Px islets, with absolute PPS activity being increased sixfold because of the higher overall glucose metabolism (both $p<0.001$ compared with the control islets at $8.3 \mathrm{mmol} / \mathrm{l}$ glucose which approximates in vivo glycaemia). Accompanying the increased PPS activity was a twofold increase in islet DNA synthesis $(p<0.005)$ (Fig. 5). As shown in Figure 1, the betacell proliferation rate 4 weeks after the Px surgery

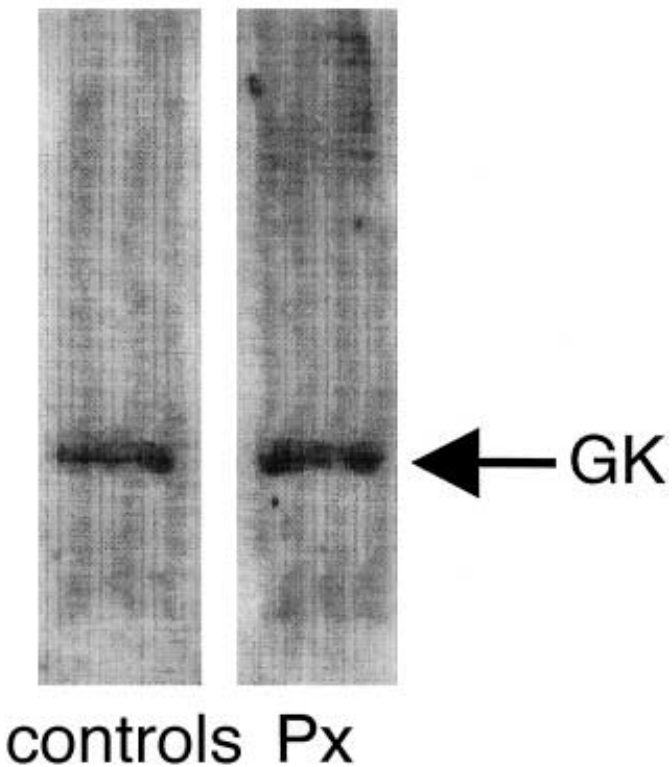

Fig. 3. Glucokinase immunoblot. Glucokinase immunoblot of isolated islets from a $60 \% \mathrm{Px}$ and control rat 5 days after surgery was done using $30 \mu \mathrm{g}$ aliquots of islet protein and sheep antiserum against an Ecoli-derived B1 isoform of rat glucokinase. The glucokinase band (GK) eluted at $52 \mathrm{kD}$

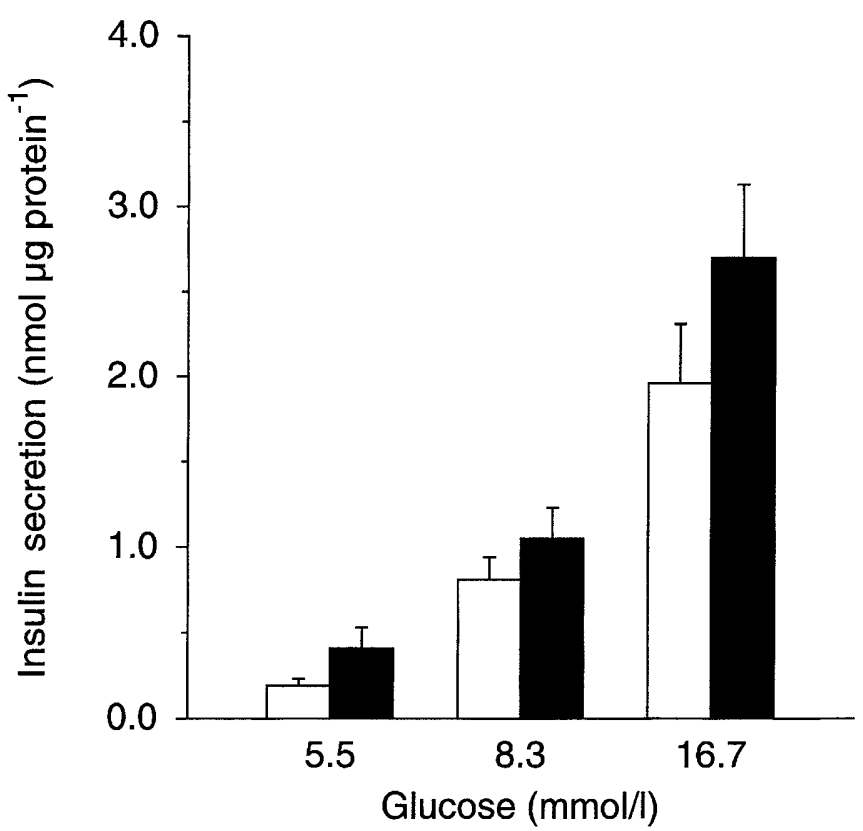

Fig. 4. Islet insulin secretion. Insulin secretion from isolated islets of $60 \% \operatorname{Px}(\square)$ and control rats $(\square) 5$ days after surgery assessed at 5.5, 8.3 and $16.7 \mathrm{mmol} / \mathrm{l}$ glucose $(n=4)$. No statistical difference between the Px and control rats was noted at any glucose concentration

was close to normal; islet PPS activity at that time was not increased (Table 1) and DNA synthesis was only minimally raised (Fig. 5).

We investigated the basis for the increased PPS activity in the 5-day Px rats. Activities of G6PD and 6- 
Table 1. Pentose phosphate shunt (PPS) activity in isolated isletsa

\begin{tabular}{|c|c|c|c|c|c|c|c|c|}
\hline \multirow[b]{2}{*}{ Parameter } & \multicolumn{3}{|c|}{ 5-day control rats $(n)$} & \multicolumn{3}{|c|}{5 -day $60 \%$ Px rats $(n)$} & \multirow{2}{*}{$\begin{array}{l}\begin{array}{l}\text { 4-week } \\
\text { control rats }(n)\end{array} \\
\begin{array}{l}8.3 \mathrm{mmol} / 1 \\
\text { glu (4) }\end{array}\end{array}$} & \multirow{2}{*}{$\begin{array}{l}\text { 4-week } 60 \% \\
\text { Px rats }(n)\end{array}$} \\
\hline & $\begin{array}{l}2.8 \mathrm{mmol} / 1 \\
\text { glu (4) }\end{array}$ & $\begin{array}{l}8.3 \mathrm{mmol} / 1 \\
\text { glu (7) }\end{array}$ & $\begin{array}{l}27.7 \mathrm{mmol} / 1 \\
\text { glu (4) }\end{array}$ & $\begin{array}{l}2.8 \mathrm{mmol} / \mathrm{l} \\
\text { glu (4) }\end{array}$ & $\begin{array}{l}8.3 \mathrm{mmol} / 1 \\
\text { glu (7) }\end{array}$ & $\begin{array}{l}27.7 \mathrm{mmol} / 1 \\
\text { glu (4) }\end{array}$ & & \\
\hline$\left[5-{ }^{3} \mathrm{H}\right]$ glucose & $42 \pm 3$ & $72 \pm 3$ & $124 \pm 13$ & $61 \pm 6^{\mathrm{a}}$ & $125 \pm 4^{\mathrm{c}}$ & $210 \pm 14^{b}$ & $75 \pm 5$ & $84 \pm 4$ \\
\hline$\left[1-{ }^{14} \mathrm{C}\right]$ glucose & $18 \pm 2$ & $28 \pm 1$ & $45 \pm 6$ & $33 \pm 5^{\mathrm{a}}$ & $63 \pm 1^{\mathrm{c}}$ & $113 \pm 4^{\mathrm{b}}$ & $52 \pm 2$ & $62+2$ \\
\hline$\left[6-{ }^{14} \mathrm{C}\right]$ glucose & $17 \pm 2$ & $24 \pm 1$ & $38 \pm 6$ & $28 \pm 5$ & $44+1^{c}$ & $82 \pm 18$ & $48 \pm 3$ & $58 \pm 4$ \\
\hline PPS (\%) & $1.8 \pm 0.2$ & $2.8 \pm 0.2$ & $3.4 \pm 0.6$ & $5.1 \pm 0.3^{c}$ & $9.3 \pm 0.5^{\mathrm{c}}$ & $11.0 \pm 1.8^{\mathrm{b}}$ & $4.7 \pm 0.5$ & $5.5 \pm 0.5$ \\
\hline
\end{tabular}

Results are means \pm SEM. Isolated islets underwent glucose tracer studies. PPS activity and per cent contribution of glucose utilization were calculated as described in the text. Units for the glucose tracer conversion studies and for the absolute
PPS activity are nmol glucose $\mathrm{mg}_{\text {protein }}{ }^{-1} 90 \mathrm{~min}^{-1}$. Statistical significance for Px versus control values at the same glucose concentration: ${ }^{\mathrm{a}} p<0.05 ;{ }^{\mathrm{b}} p<0.005 ;{ }^{\mathrm{c}} p<0.001$
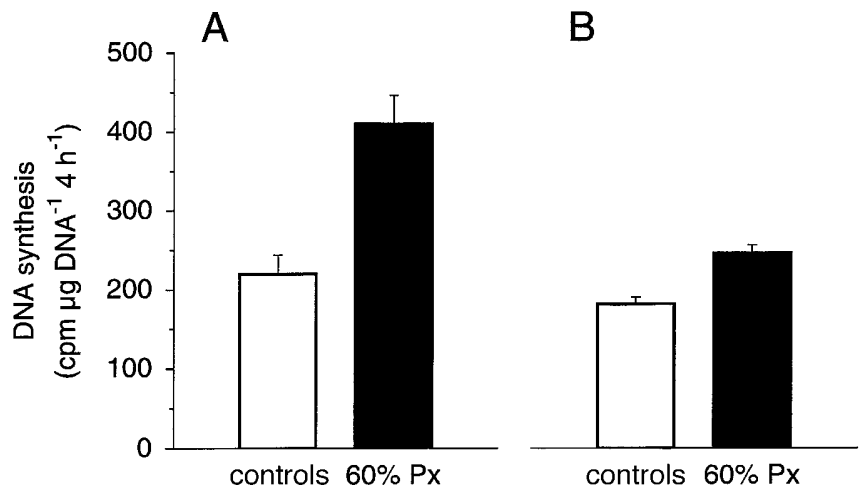

Fig. 5. Islet DNA synthesis. Isolated islets from $60 \% \mathrm{Px}$ and control rats 5 days after surgery $(\mathbf{A})(n=4)$ or 4 weeks after surgery (B) $(n=3)$ were incubated for $4 \mathrm{~h}$ with $2 \mu \mathrm{Ci}[3 \mathrm{H}]$ thymidine at $8.3 \mathrm{mmol} / \mathrm{l}$ glucose. Incorporation of $\left[{ }^{3} \mathrm{H}\right]$ thymidine into DNA was measured as described in the text. Px values were $189 \pm 9 \%$ at 5 days $(p<0.015)$ and $135 \pm 7 \%$ at 4 weeks $(p<0.015)$ of the controls

PGD which are key regulatory enzymes of the PPS pathway were increased $50 \%$ in Px islets [11] (Table 2). We also determined the concentration of the PPS substrate, G6P, following $60 \mathrm{~min}$ exposure to $2.8,8.3$ or $27.7 \mathrm{mmol} / 1$ glucose. The G6P concentration was twofold increased in the Px islets at all glucose concentrations (Fig. 6A). There was also a linear relation between islet G6P concentration and PPS activity (Fig. 6B).

Islet PFK and citrate synthase activities. The G6P concentration reflects the balance between its production and metabolism. Glucose phosphorylation was increased in the Px islets as already shown. The main regulator of post-glucokinase glycolytic flux in beta cells, and thus G6P metabolism, is PFK [27, 28] which is regulated transcriptionally and also by multiple allosteric activators and inhibitors. Citrate produced from citrate synthase is the main inhibitor [29]. PFK and citrate synthase $\mathrm{V}_{\max }$ did not change in the Px islets (Table 2). Citrate concentration after 1-h expo-
Table 2. Enzyme activities in isolated isletsa

\begin{tabular}{|c|c|c|c|}
\hline Parameter & $\begin{array}{l}\text { Control rats } \\
(n)\end{array}$ & $\begin{array}{l}60 \% \text { Px rats } \\
(n)\end{array}$ & $p$ \\
\hline $\begin{array}{l}\text { G6PD }(\mu \mathrm{mol} \mathrm{mg} \\
\left.\text { protein }^{-1} \mathrm{~min}^{-1}\right)\end{array}$ & $25 \pm 1(4)$ & $37 \pm 4(4)$ & 0.02 \\
\hline $\begin{array}{l}\text { 6-PGD }(\mu \mathrm{mol} \mathrm{mg} \\
\left.\text { protein }^{-1} \mathrm{~min}^{-1}\right)\end{array}$ & $18 \pm 1(4)$ & $27 \pm 3(4)$ & 0.03 \\
\hline $\begin{array}{l}\text { PFK }(\mathrm{nmol} \mathrm{mg} \\
\left.\text { protein }^{-1} \min ^{-1}\right)\end{array}$ & $73 \pm 7(4)$ & $106 \pm 5(4)$ & NS \\
\hline $\begin{array}{l}\text { Citrate synthase (nmol } \\
\left.\text { mg protein }{ }^{-1} \min ^{-1}\right)\end{array}$ & $135 \pm 8(4)$ & $200 \pm 49(4)$ & NS \\
\hline
\end{tabular}

Results are means \pm SEM. Statistical significance was determined by the unpaired Students $t$ test

sure to $8.3 \mathrm{mmol} / \mathrm{l}$ glucose was twofold higher in $\mathrm{Px}$ islets $\left(5.8 \pm 0.5 \mathrm{nmol} \mathrm{mg}\right.$ protein ${ }^{-1} \mathrm{Px}$ vs. $2.7 \pm 0.2$ nmol mg protein $\left.{ }^{-1}, n=4, p=0.002\right)$.

Islet glucose-derived lipid and amino acid production. Glucose-derived lipid production was increased in Px islets $(167 \pm 5 \%$ of control rats at $8.3 \mathrm{mmol} / \mathrm{l}$ glucose, $p<0.002$ ) with no difference in the proportion of glucose utilization that went to lipid production between the control and Px islets (Fig. 7). Comparable results were obtained for glucose-derived alanine and glutamate production (Fig.8) although the amount of increase in the $\mathrm{Px}$ islets was somewhat larger $(271 \pm 39 \%$ at $8.3 \mathrm{mmol} / \mathrm{l}$ glucose $)$.

\section{Discussion}

The glucose homeostasis system maintains normoglycaemia by varying insulin secretion through changes in both the mass and function of beta cells. We studied $60 \%$ Px rats to gain insight into the beta-cell compensation that follows a partial pancreatectomy which results in a lowered beta-cell mass. We previously studied these rats 4 weeks after surgery and identified enhanced insulin secretion on the basis of increased glucokinase activity [6]. The current study 

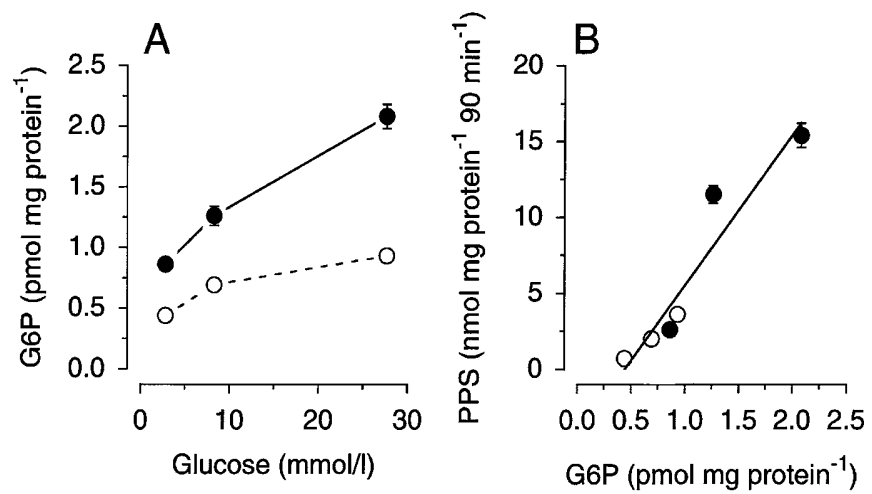

Fig. 6. Islet G6P concentration $(\mathbf{A})$ and the relation between islet G6P concentration and PPS activity (B). Freshly isolated islets from rats 5 days after $60 \% \mathrm{Px}$ or control Px (A) were incubated in $2.8,8.3$ and $27.7 \mathrm{mmol} / 1$ glucose for $60 \mathrm{~min}$ followed by measurement of G6P as described in the text ( $n=4$ experiments). Px values were statistically increased at all tested glucose concentrations ( $p<0.001$ at all glucose concentrations). The mean G6P results graphed against the PPS activity from Table 1 (B) measured at the same experimental conditions shows a linear relation
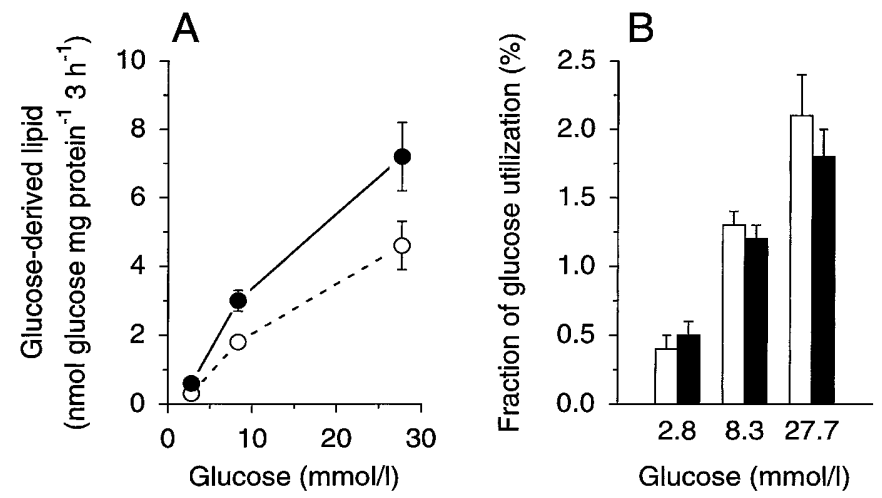

Fig. 7. Glucose-derived lipid production $(\mathbf{A})$ and percent of glucose utilization $(\mathbf{B})$ in isolated islets. Freshly isolated islets from rats 5 days after $60 \%$ Px or control Px (A) were incubated in 2.8, 8.3 and $27.7 \mathrm{mmol} / \mathrm{l}$ glucose and $4 \mu \mathrm{Ci}$ [U_- ${ }^{14} \mathrm{C}$ ]glucose ( $n=6-8$ experiments) for $60 \mathrm{~min}$. Glucose-derived lipid was measured in chloroform-methanol extracts. Statistical values for the Px versus control groups were $p<0.05$ at $2.8 \mathrm{mmol} / \mathrm{l}$ glucose, $p<0.002$ at $8.3 \mathrm{mmol} / \mathrm{l}$ glucose, $p=\mathrm{NS}$ at $27.7 \mathrm{mmol} / \mathrm{l}$ glucose. Per cent of islet glucose utilization that was made up of glucose-derived lipid production (B) was calculated by comparing the results from (A) to the $\mathrm{D}-\left[5-{ }^{3} \mathrm{H}\right]$ glucose-calculated glucose utilization results from Table 1

was done 5 days after a $60 \% \mathrm{Px}$, a time characterized not only by increased glucokinase activity (to a greater extent than at 4 weeks) but also by a threefold increase in beta-cell proliferation. Production of glucose-derived lipid and amino acids increased in the Px islets. Also, there was a marked increase in PPS activity and DNA synthesis that was not present when beta-cell proliferation was only minimally increased (4 weeks). These findings show that increased glucokinase activity and the resulting in-
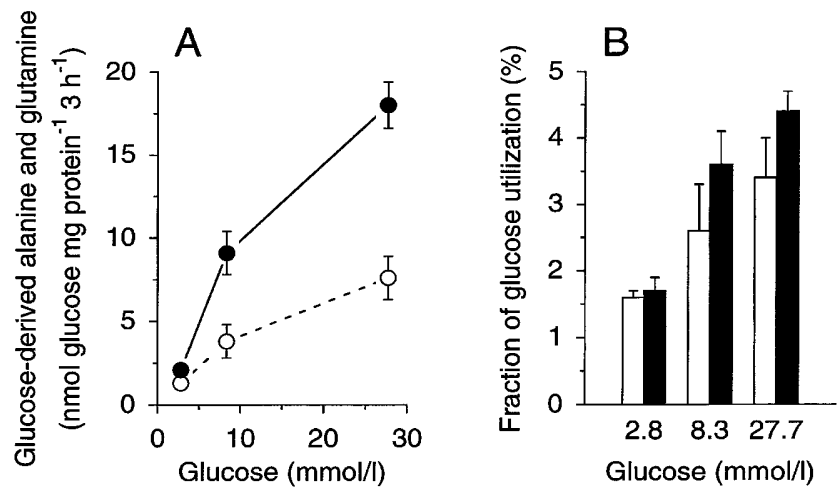

Fig. 8. Glucose-derived alanine and glutamate production (A) and per cent of glucose utilization $(\mathbf{B})$ in isolated islets. Freshly isolated islets from rats 5 days after $60 \%$ Px or control Px (A) were incubated in $2.8,8.3$ and $27.7 \mathrm{mmol} / 1$ glucose and $1 \mu \mathrm{Ci}$ $\left[6-{ }^{14} \mathrm{C}\right]$ glucose $(n=4$ experiments) for $60 \mathrm{~min}$. Glucose-derived alanine and glutamate production was measured as described in the text. Statistical values for the Px versus control groups were $p<0.03$ at $2.8 \mathrm{mmol} / \mathrm{l}$ glucose, $p<0.02$ at $8.3 \mathrm{mmol} / \mathrm{l}$ glucose, $p<0.002$ at $27.7 \mathrm{mmol} / 1$ glucose. Per cent of islet glucose utilization that was made up of glucose-derived alanine and glutamate production (B) was calculated by comparing the results from $(\mathbf{A})$ to the $\mathrm{D}-\left[5-{ }^{3} \mathrm{H}\right]$ glucose-calculated glucose utilization results from Table 1

crease in glucose metabolism in the 5 day Px islets is associated with augmented production of DNA, lipid and amino acids, and could provide an insight into the recently identified requirement of glucokinase in fatfeeding-induced compensatory beta-cell growth [9]. Surprisingly, glucose-induced insulin secretion did not increase in the 5-day Px islets. The long-standing observation of a lack of glucose responsiveness in fetal islet tissue $[30,31]$, despite the presence and activity of glucokinase [32], suggests that alternate steps in the stimulus secretion mechanism require additional maturation. It could be the newly developed beta cells in the 5-day Px islets are not yet fully mature for normal function.

The sixfold increase in PPS activity in the Px islets is of particular interest as an important role has been postulated for this metabolic pathway in normally regulated and dysregulated cell proliferation based on studies that have shown increased PPS activity in hyperproliferating tissues and a wide variety of cancers and tumor cells [23, 33-36]. The PPS converts G6P for several purposes: synthesis of ribo-nucleotides and deoxyribonucleotides from ribose-5-phosphate, non-oxidative branch that produces glyceraldehyde-3-phosphate which is an important signalling molecule for insulin secretion and oxidative branch that returns to the glycolytic pathway [11]. Furthermore, the generated NADPH is utilized, depending on the tissue, for lipid production, maintenance of the redox state, and defence against nitric oxide-mediated or other forms of cell death $[11,37,38]$. The marked enhancement of PPS activity in 5-day Px is- 
lets contrasts with previous studies of beta cells and islets that showed little PPS activity [10, 39], analogous to 4-week Px islets. Thus, akin to the cited studies in neoplastic and highly replicative normal tissues, there appears to be a correlation between PPS activity and beta-cell proliferation. We cannot determine from our results if increases in PPS activity have a regulatory role in beta-cell hyperproliferation as has been shown in a kidney cell line based on genetic and pharmacologic manipulation of glucose-6-phosphate dehydrogenase activity, and thus of PPS activity, that resulted in parallel changes in cell growth and thymidine incorporation [23]. However, it is notable that 4-week Px islets had no increase in PPS activity and there were close to normal rates of DNA synthesis and beta-cell proliferation.

Why did PPS activity increase in the Px rats 5 days after the surgery, but not at 4 weeks, as both times show increased glucokinase activity and islet glucose metabolism? We propose the key factor is the amount of increase in glucokinase activity $-180 \%$ of control in the 4-week Px rats [6] and more than $300 \%$ of control in the current study - based on adenovirus-mediated increases of glucokinase expression in beta cells [40]. Investigators observed a narrow range of effect whereby more than a twofold increase in glucokinase activity no longer increased glucose metabolism but raised instead the G6P concentrations because of a limiting downstream capacity for glucose metabolism. Consistent with this view, G6P concentrations were increased in the 5-day Px islets but not at 4 weeks using the same experimental protocol [6]. Furthermore, there was a mismatch in glucose phosphorylation ( $>$ threefold increased) and glucose utilization ( < twofold increased) in 5-day Px islets as opposed to identical amounts of change (both $180 \%$ of control) at 4 weeks [6]. The linear relation between G6P concentration and islet PPS activity in this study is additional support. Thus, our results coupled with the study of glucokinase overexpression in beta cells [40] support an effect of the enhanced glucose phosphorylation in 5-day Px islets to increase flux through the PPS pathway. To be active, that response requires glucose phosphorylation to exceed the glycolytic capacity which explains the lack of this effect in 4-week Px rats.

What determines the post glucokinase capacity for glucose metabolism in beta cells and thus the G6P concentration? Computer modelling of beta-cell glucose metabolism has shown that when glucokinase is normally active, it is rate-limiting for glycolytic flux [28]. However, glycolysis is oscillatory in beta cells, with activation and deactivation of PFK postulated to be the cause [27]. It is thus thought that PFK affects glycolysis but its influence is normally on the character, not on the overall flux. In turn, increases in glucose phosphorylation that outstrip PFK capacity would cause that enzyme's activity to be rate-limiting. Our results support this possibility when compared with how chronic high glucose affects beta-cell glucose metabolism. In Px islets, production of citrate, the major allosteric inhibitor for PFK [29], was doubled and there was no change in PFK $V_{\max }$ in tandem with the observed mismatch in glucose phosphorylation (threefold increased) and glucose utilization ( $<$ twofold increased). High glucose-induced increases in glucokinase activity [41, 42] are accompanied instead by increased PFK gene expression and lowered citrate synthase-induced production of citrate [19]. Of note, there is no loss of the primacy of glucokinase to determine glucose utilization as shown in a previous study in which rat islets were cultured for 7 days at various glucose concentrations [41]; islets cultured at $30 \mathrm{mmol} / 1$ glucose had threefold increases in both glucokinase $\mathrm{V}_{\max }$ and glucose utilization. This dichotomy regarding PFK activity in Px and high glucose-cultured islets supports an important role in determining G6P metabolism when beta-cell glucokinase activity is increased.

In summary, this study confirmed our finding of increased beta-cell glucokinase activity made 4 weeks after a $60 \% \mathrm{Px}[6]$. The 5-day time point is also characterized by compensatory beta-cell hyperproliferation or growth providing an opportunity to investigate how the enhanced glucose metabolism influences or supports this aspect of the adaptation process. The increase in glucokinase activity in 5-day Px islets was considerably larger than at 4 weeks and at this point exceeded the downstream capacity for glycolysis. Consequently, the G6P level rose, and PPS activity increased in association with a doubling of DNA synthesis. None of these effects were present with the more moderate increase in glucokinase activity of the 4week Px islets, a time when the rate of beta-cell proliferation was nearly normal. An additional effect of the higher glucokinase activity and glucose metabolism was to increase the production of glucose-derived lipid and amino acids. We propose that the marked increase in glucokinase activity 5 days after the $60 \%$ Px supports the compensatory beta-cell hyperproliferation through an increase in production of glucose-derived DNA, lipid and amino acids.

Acknowledgements. This work was supported by grants from the American Diabetes Association (JLL), the National Institutes of Health DK56818 (JLL), and the Comisión Interministerial de Ciencia y Tecnologia (CICYT, Government of Spain) grant SAF 97-0118 (EM). We thank Peter Nevin and Olga Aranda for expert technical assistance.

\section{References}

1. Meglasson MD, Matschinsky FM (1986) Pancreatic islet glucose metabolism and regulation of insulin secretion. Diabetes Metab Rev 2: 163-214

2. Bonner-Weir S, Deery D, Leahy JL, Weir GC (1989) Compensatory growth of pancreatic beta-cells in adult rats after shortterm glucose infusion. Diabetes 38: 49-53 
3. Hutton JC (1994) Insulin secretory granule biogenesis and the proinsulin-processing endopeptidases. Diabetologia 37 [Suppl 2]: S48-S56

4. Newgard CB, McGarry JD (1995) Metabolic coupling factors in pancreatic beta-cell signal transduction. Annu Rev Biochem 64: 689-719

5. Polonsky KS, Given BD, Van Cauter E (1988) Twenty-fourhour profiles and pulsatile patterns of insulin secretion in normal and obese subjects. J Clin Invest 81: 442-448

6. LiuYQ, Nevin PW, Leahy JL (2000) $\beta$-cell adaptation in $60 \%$ pancreatectomy rats that preserves normoinsulinemia and normoglycemia. Am J Physiol 279: E68-E73

7. Chen C, Hosokawa H, Bumbalo LM, Leahy JL (1994) Mechanism of compensatory hyperinsulinemia in normoglycemic insulin-resistant spontaneously hypertensive rats. Augmented enzymatic activity of glucokinase in beta-cells. J Clin Invest 94: 399-404

8. Matschinsky FM (1996) A lesson in metabolic regulation inspired by the glucokinase glucose sensor paradigm. Diabetes 45: $223-241$

9. Terauchi Y, Komeda K, Kubota N et al. (2000) Failure of compensatory $\beta$-cell hyperplasia in heterozygous glucokinase-deficient mice under a high-fat diet. Diabetes 49 [Suppl 1] A62 (Abstract)

10. Schuit F, De Vos A, Farfari S et al. (1997) Metabolic fate of glucose in purified islet cells. Glucose-regulated anaplerosis in beta cells. J Biol Chem 272: 18572-18579

11. Kletzien RF, Harris PK, Foellmi LA (1994) Glucose-6-phosphate dehydrogenase: a "housekeeping" enzyme subject to tissue-specific regulation by hormones, nutrients, and oxidant stress. FASEB J 8: 174-181

12. Leahy JL, Bonner-Weir S, Weir GC (1988) Minimal chronic hyperglycemia is a critical determinant of impaired insulin secretion after an incomplete pancreatectomy. J Clin Invest 81: 1407-1414

13. Gotoh M, Maki T, Satomi S et al. (1987) Reproducible high yield of rat islets by stationary in vitro digestion following pancreatic ductal or portal venous collagenase injection. Transplantation 43: 725-730

14. Labarca C, Paigen KD (1980) A simple, rapid, and sensitive DNA assay procedure. Anal Biochem 102: 344-352

15. Albano JDM, Ekins RP, Maritz G, Turner RC (1972) A sensitive, precise radioimmunoassay of serum insulin relying on charcoal separation of bound and free hormone moieties. Acta Endocrinol 70: 487-509

16. Liang Y, Najafi H, Matschinsky FM (1990) Glucose regulates glucokinase activity in cultured islets from rat pancreas. J Biol Chem 265: 16863-16866

17. Verspohl EJ, Breuning I, Ammon HPT (1989) Effect of CCK-8 on pentose phosphate shunt activity, pyridine nucleotides, and glucokinase of rat islets. Am J Physiol 256: E68-E73

18. Baas AS, Berk BC (1995) Differential activation of mitogenactivated protein kinases by $\mathrm{H}_{2} \mathrm{O}_{2}$ and $\mathrm{O}_{2}$ in vascular smooth muscle cells. Circ Res 77: 29-36

19. Roche E, Farfari S, Witters LA et al. (1998) Long-term exposure of beta-INS cells to high glucose concentrations increases anaplerosis, lipogenesis, and lipogenic gene expression. Diabetes 47: 1086-1094

20. Sener A, Malaisse WJ (1987) Stimulation by D-glucose of mitochondrial oxidative events in islet cells. Biochem J 246: 89-95

21. Liu YQ, Tornheim K, Leahy JL (1998) Shared biochemical properties of glucotoxicity and lipotoxicity in islets decrease citrate synthase activity and increase phosphofructokinase activity. Diabetes 47: 1889-1893

22. Liu YQ, Tornheim K, Leahy JL (1998) Fatty acid-induced beta cell hypersensitivity to glucose. Increased phosphofructokinase activity and lowered glucose-6-phosphate content. J Clin Invest 101: $1870-1875$

23. Tian WN, Braunstein LD, Pang J et al. (1998) Importance of glucose-6-phosphate dehydrogenase activity for cell growth. J Biol Chem 273: 10609-10617

24. Lowry OH, Passonneau JV (1972) A Flexible System of Enzymatic Analysis, Academic Press, New York, pp 157-158

25. Lowry OH, Passonneau JV (1972) A Flexible System of Enzymatic Analysis, Academic Press, New York, pp 179-182

26. Nacher V, Merino JF, Raurell M, Soler J, Montanya E (1998) Normoglycemia restores $\beta$-cell replicative response to glucose in transplanted islets exposed to chronic hyperglycemia. Diabetes 47: 192-196

27. Tornheim K (1997) Are metabolic oscillations responsible for normal oscillatory insulin secretion? Diabetes 46: 1375-1380

28. Sweet IR, Matschinsky FM (1995) Mathematical model of beta-cell glucose metabolism and insulin release. I. Glucokinase as glucosensor hypothesis. Am J Physiol 268: E775-E788

29. Kemp RG, Foe LG (1983) Allosteric regulatory properties of muscle phosphofructokinase. Mol Cell Biochem 57: 147-154

30. Otonkoski T, Andersson S, Knip M, Simell O (1988) Maturation of insulin response to glucose during human fetal and neonatal development. Diabetes 37: 286-291

31. Rorsman P, Arkhammar P, Bokvist K et al. (1989) Failure of glucose to elicit a normal secretory response in fetal pancreatic beta cells results from glucose insensitivity of the ATP-regulated $\mathrm{K}^{+}$channels. Proc Natl Acad Sci USA 86: 4505-4509

32. Tu J, Tuch BE (1997) Expression of glucokinase in glucose-unresponsive human fetal pancreatic islet-like cell clusters. J Clin Endocrinol Metab 82: 943-948

33. Boros LG, Lee PW, Brandes JL et al. (1998) Nonoxidative pentose phosphate pathways and their direct role in ribose synthesis in tumors: is cancer a disease of cellular glucose metabolism? Med Hypotheses 50: 55-59

34. Nowak G, Schnellmann RG (1995) Integrative effects of EGF on metabolism and proliferation in renal proximal tubular cells. Am J Physiol 269: C1317-C1325

35. Downs SM, Humpherson PG, Leese HJ (1998) Meiotic induction in cumulus cell-enclosed mouse oocytes: involvement of the pentose phosphate pathway. Biol Reprod 58: 1084-1094

36. Boros LG, Puigjaner J, Cascante M et al. (1997) Oxythiamine and dehydroepiandrosterone inhibit the nonoxidative synthesis of ribose and tumor cell proliferation. Cancer Res 57: $4242-4248$

37. Tian WN, Braunstein LD, Apse K et al. (1999) Importance of glucose-6-phosphate dehydrogenase activity in cell death. Am J Physiol 276: C1121-C1131

38. García-Nogales P, Almeida A, Fernandez E, Medina JM, Bolanos JP (1999) Induction of glucose-6-phosphate dehydrogenase by lipopolysaccharide contributes to preventing nitric oxide-mediated glutathione depletion in cultured rat astrocytes. J Neurochem 72: 1750-1758

39. Ashcroft SJ, Weerasinghe LC, Bassett JM, Randle PJ (1972) The pentose cycle and insulin release in mouse pancreatic islets. Biochem J 126: 525-532

40. Wang H, Iynedjian PB (1997) Modulation of glucose responsiveness of insulinoma beta-cells by graded overexpression of glucokinase. Proc Natl Acad Sci USA 94: 4372-4377

41. Liang Y, Jetton TL, Zimmerman EC et al. (1994) Effects of glucose on insulin secretion, glucokinase activity, and transgene expression in transgenic mouse islets containing an upstream glucokinase promoter-human growth hormone fusion gene. Diabetes 43: 1138-1145

42. Gasa R, Fabregat ME, Gomis R (2000) The role of glucose and its metabolism in the regulation of glucokinase expression in isolated human pancreatic islets. Biochem Biophys Res Commun 268: 491-495 